\title{
FUEL GASES FROM WASTE HIGH DENSITY POLYETHYLENE (HDPE) VIA LOW TEMPERATURE CATALYTIC PYROLYSIS
}

\section{Surma, Nguamo*, Ijuo, Godwin Abawulo, Ogoh-Orch, Blessing} Chemistry Department, College of Science, University of Agriculture, PMB 2373, Makurdi, Benue State, Nigeria

\section{AR T I C L E I N F O}

\section{Article history:}

Submitted: 2019-11-23

Revised: 2019-11-20

Accepted: 2019-12-01

Available online: 2019-12-20

Manuscript ID: PCBR-1911-1071

\section{G R A P H I C A L A B S T RA C T}

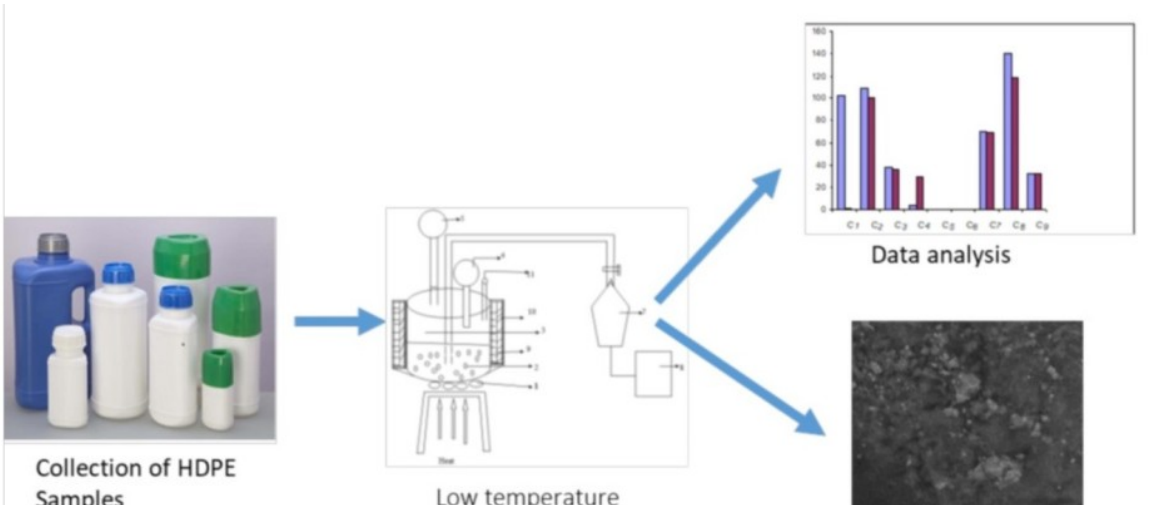

\section{K E Y W O R D S}

Pyrolysis

HDPE

FCC catalyst

Fuel gases 


\section{Introduction}

Plastics have become the material of choice in modern world and its application in the industrial field is continually increasing [1]]. The amount of plastic waste is growing every year and with that comes an environmental concern regarding this problem. This increase in the amount of waste does cause some environmental problems, since plastics do not degrade quickly and can remain in the environment for a very long time $[\underline{2}, \underline{3}]$. Their destruction by incineration and land filling poses serious environmental problems due to the release of airborne particles and carbon (iv) oxide into the atmosphere [4]. Both processes do not allow the recovery of the organic component of the waste plastic which could be part of organic life-cycle [ $\underline{5}$. Feedstock recycling of plastic waste includes processes that transform plastic waste to their constituent monomers or basic hydrocarbon feedstock. Recycling has several meanings with regards to plastics and can be divided into primary, secondary, tertiary and quaternary forms of recycling []].

The processing of plastic for use comparable to the original application and the processing of plastic waste into new products with lower quality level is called primary and secondary recycling respectively. Quatenary recycling involves incineration of plastic waste to recover energy. This study is concerned with tertiary recycling which deals with pyrolysis or catalytic processing of plastic waste into their hydrocarbon feedstock thereby returning the waste plastic to their constituent monomers and basic hydrocarbon [1]. Tertiary recycling of waste can be considered not only as a solution for waste plastic disposal but also for generating an environmentally acceptable transportation fuel or feedstock for transportation of virgin plastic []].

\section{Experimental}

\subsection{HDPE sample collection and preparation}

The high density polyethylene waste (HDPE) were mainly collected from pharmaceutical stores as refuse and several dumping sites around Makurdi town, Benue State of Nigeria. The samples were washed thoroughly using detergent and rinsed properly with deionized water, then dried at room temperature to remove all moisture. The dried samples were reduced into smaller bits to increase the surface area. The Fluid Cracking (FCC) catalytic employed for this work was obtained from Nigerian National Cooperation (NNPC) Warri in Delta State and is shown by analysis to be composed of aluminum and silicon. Scanning Election Microscopy (SEM) images of the fresh FCC catalyst were obtained at magnifications of 1000 x, 2500 x, 5000 $\mathrm{x}, 10000 \mathrm{x}$, and $15000 \mathrm{x}$ respectively. Scanning electron microscopy (SEM) images of the spent FCC catalyst were obtained at magnification of $500 \mathrm{x}$, 1000 x, 2150 x, 5000 x, and 10000 x. From the SEM images, it was deduced that the catalyst particle size ranged within $5 \mu \mathrm{m}-80 \mu \mathrm{m}$ while the spent FCC catalyst gave particle sizes within the range of $8 \mu \mathrm{m}$ $100 \mu \mathrm{m}$. In further characterizing the fresh and spent FCC catalyst, SEM was combined with atomic absorption spectrometry (AAS) in the detection of 
the metal composition. The analysis indicated the presence of aluminum (5.122 and silicon $3.375 \mathrm{ppm}$ ) and silicon (6.480 and $5.270 \mathrm{ppm}$ ) respectively.

\subsection{Experimental Procedure}

Fig. 1 shows the layout of the pyrolysis process. A pressure pot made of stainless steel of height 30.00 $\mathrm{cm}$ with an internal diameter of $31.50 \mathrm{~cm}$ was adapted for the pyrolysis reaction $[\underline{7}, \underline{8}]$. The cover had an outlet tube at the top for collection of the evolved gases. The reactor was effectively lagged with a fire blanket and placed in sand bath constructed with iron sheets for good heat retention. The reactor fitted in the sand bath was heated with three Mekker burners in order to attain the required temperatures which were controlled by means of a thermocouple. Tedlar bags were used for collection of the evolved gases. These gases were immediately sent for gas chromatogram for analyses.

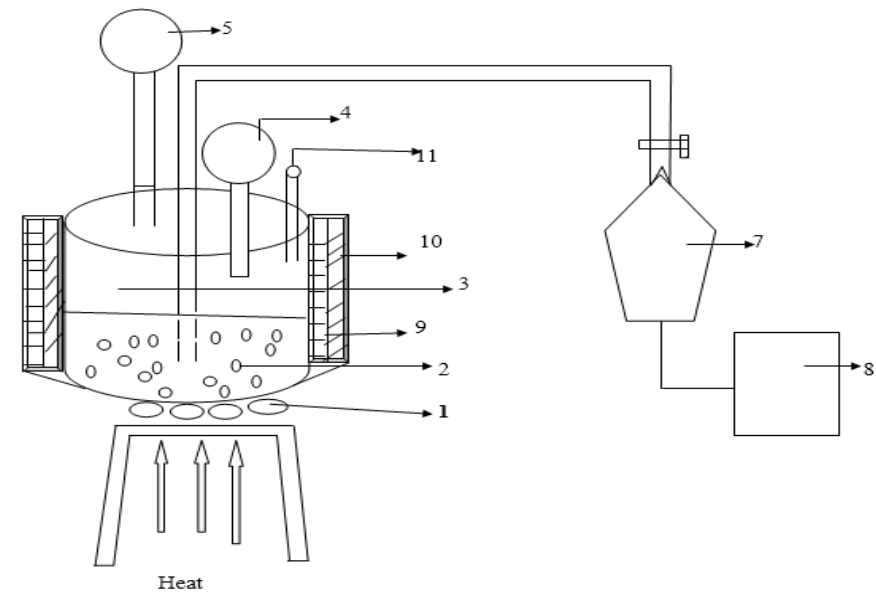

Fig. 1. Layout of the pyrolysis process, 1.Heating mantle, 2.Waste material/ catalyst, 3.Reactor, 4.Pressure, 5.Thermocouple, 6.Regulator, 7. Tedlar gas sampling long beg, 8.G.C Analyzer, 9.Lagging material, 10.Sand bath, 11.Stopered inlet

\subsection{Catalytic Cracking of HDPE}

Two catalyst/sample ratios (1:8 and 1:16) were investigated in the catalyzed pyrolysis [9]. The sample (polymer material $200 \mathrm{~g}$ ) was placed at the bottom while the catalyst material was arranged in sandwich layers within the polymer sample [10]. The reactor was covered and heating commenced. After 30 minutes into the reaction, evolution of gases started slightly and this was evident as bag began to swell. After heating for about $11 / 2$ hours at $250{ }^{\circ} \mathrm{C}$, the system was shut down. The gases which were collected at $150{ }^{\circ} \mathrm{C}$ and $250{ }^{\circ} \mathrm{C}$ in labeled tedlar bags were analyzed. The system was shut down allowed to cool before the reactor was opened. The residue for each run was weighed.

\subsection{Gas Chromatography Analysis}

The gaseous products obtained from pyrolysis of HDPE with the effect of both fresh and spent FCC catalyst were characterized using a Buck 530 gas chromatography with HP-88 $(10 \mathrm{~m} / 0.25 \mathrm{~mm}$ thickness) injection volume was $10 \mu \mathrm{L}$ with helium as the mobile phase and flame ionization detector (FID), injection and detection temperature were 250 ${ }^{\circ} \mathrm{C}$ and $280{ }^{\circ} \mathrm{C}$ respectively.

\section{RESULTS AND DISCUSSION}

Fig. 2 and 3 shows the SEM image of fresh FCC and spent FCC catalyst at different resolutions respectively. The HDPE waste employed for this work consisted of a mixture of polyethylene ranging from pharmaceutical, cosmetic, and yoghurt waste bottles. 


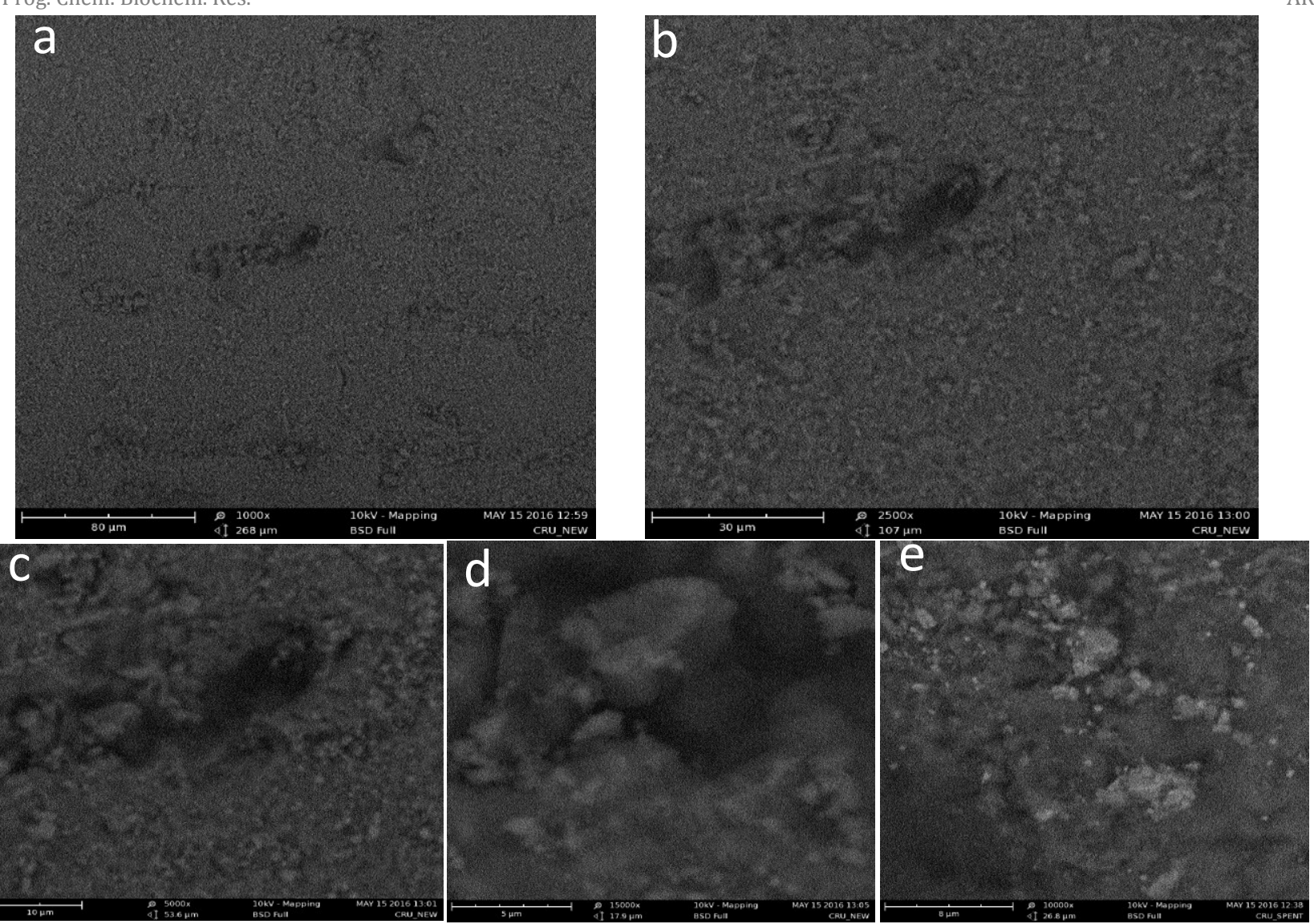

Fig. 2. SEM image of fresh FCC catalyst at: (a) 1000 X (b) 2500 X (c) $5000 X$ (d) 10000 X (e) $15000 \mathrm{X}$
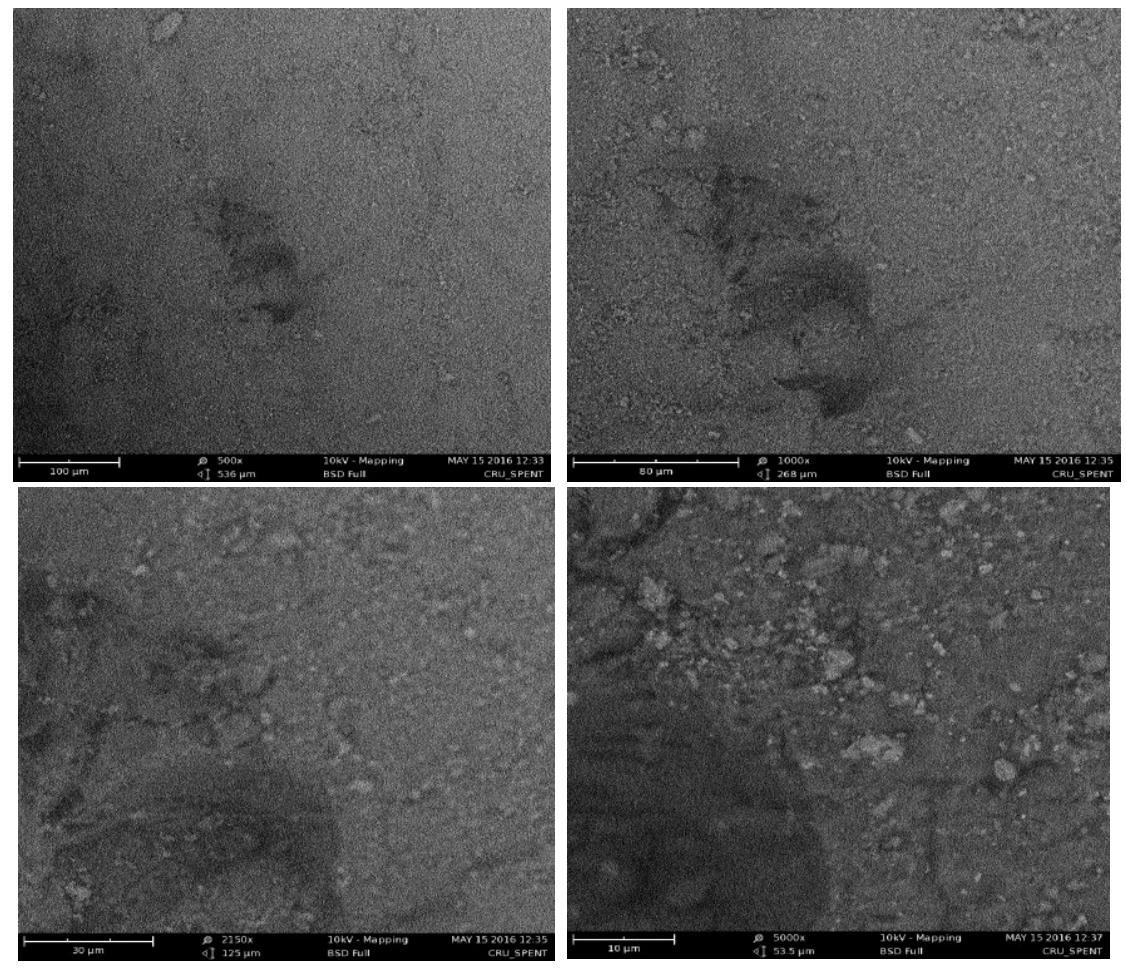

Fig. 3. SEM image of spent FCC catalyst at: (a) $500 \mathrm{X}$ (b) $1000 \mathrm{X}$ (c) $2150 \mathrm{X}$ (d) $5000 \mathrm{X}$ 
At the end of the pyrolysis reaction the residue obtained weighed (120 g / $125 \mathrm{~g}$ ) and (100 g / 120 g) were obtained for the reactions which occurred at catalyst/sample ratios of 1:8 and 1:16 respectively.
Comparative composition of the gases evolved from pyrolysis of waste HDPE at $150{ }^{\circ} \mathrm{C}$ and $250{ }^{\circ} \mathrm{C}$ using catalyst/sample ratio 1:8 is presented in Table 1.

Table 1: Composition of gases obtained from pyrolysis HDPE at $150{ }^{\circ} \mathrm{C}$ and $250{ }^{\circ} \mathrm{C}$ using fresh FCC catalyst with the catalyst/sample ratio of 1:8 after heating for one and a half hours

\begin{tabular}{cccccc}
\hline \multirow{2}{*}{ Component } & \multirow{2}{*}{$\begin{array}{c}\text { Organic } \\
\text { compound }\end{array}$} & $\begin{array}{c}\text { Reaction at } \mathbf{1 5 0}{ }^{\circ} \mathbf{C} \\
\text { Reaction at } \mathbf{2 5 0}{ }^{\circ} \mathbf{C}\end{array}$ \\
\cline { 3 - 6 } & & $\begin{array}{c}\text { Contration } \\
\text { npm })\end{array}$ & $\begin{array}{c}(\%) \\
\text { Concentration }\end{array}$ & $\begin{array}{c}\text { Concentration } \\
(\mathrm{ppm})\end{array}$ & $\begin{array}{c}(\%) \\
\text { concentration }\end{array}$ \\
\hline $\mathrm{C}_{1}$ & n-Methane & 2.4302 & 2.8794 & 0.3581 & 0.0680 \\
$\mathrm{C}_{2}$ & n-Ethane & 17.3379 & 20.5430 & 152.9042 & 29.0460 \\
$\mathrm{C}_{3}$ & n-Propane & 10.7678 & 12.7580 & 30.4614 & 5.7866 \\
$\mathrm{C}_{4}$ & n-Butane & 4.9829 & 5.9041 & 33.5059 & 6.3650 \\
$\mathrm{C}_{5}$ & n-Pentane & Nil & Nil & Nil & Nil \\
$\mathrm{C}_{6}$ & n-Hexane & 2.7615 & 3.2720 & 8.4647 & 1.6080 \\
$\mathrm{C}_{7}$ & n-Heptane & 15.3558 & 18.194 & 79.5571 & 15.1130 \\
$\mathrm{C}_{8}$ & n-Octane & 16.8334 & 19.9450 & 127.8764 & 24.2920 \\
$\mathrm{C}_{9}$ & n-Nonane & 13.9274 & 16.5020 & 93.2789 & 17.7190 \\
Total & & $\mathbf{8 4 . 3 9 6 9}$ & & $\mathbf{5 2 6 . 4 0 7 0}$ & \\
\hline
\end{tabular}

Table 2: Composition of gases obtained from pyrolysis of HDPE at $150{ }^{\circ} \mathrm{C}$ and $250{ }^{\circ} \mathrm{C}$ using fresh FCC catalyst in the ratio of 1:16 after heating for one and a half hours

\begin{tabular}{cccc}
\hline \multirow{2}{*}{ Component } & Name & $\begin{array}{c}\text { Reaction at } \mathbf{1 5 0} \mathbf{C}^{\circ} \\
\text { Concentration } \\
(\mathrm{ppm})\end{array}$ & $\begin{array}{c}\text { Reaction at } \mathbf{2 5 0} \mathbf{C}^{\circ} \\
(\mathrm{ppm})\end{array}$ \\
\hline $\mathrm{C}_{1}$ & n-Methane & 101.9239 & 0.7633 \\
$\mathrm{C}_{2}$ & n-Ethane & 108.9239 & 100.2590 \\
$\mathrm{C}_{3}$ & n-Propane & 38.3533 & 36.1316 \\
$\mathrm{C}_{4}$ & n-Butane & 4.1603 & 28.9361 \\
$\mathrm{C}_{5}$ & n-Pentane & Nil & Nil \\
$\mathrm{C}_{6}$ & n-Hexane & Nil & Nil \\
$\mathrm{C}_{7}$ & n-Heptane & 69.4687 & 69.1586 \\
$\mathrm{C}_{8}$ & n-Octane & 140.6610 & 118.4262 \\
$\mathrm{C}_{9}$ & n-Nonane & 32.0212 & 31.8353 \\
Total & & $\mathbf{4 9 5 . 4 3 1 5}$ & $\mathbf{3 8 5 . 5 1 0 1}$ \\
\hline
\end{tabular}


In Table 1 and Fig. 4 , the reaction occurred at a catalyst/sample ratio of 1:8 and the concentration of gases obtained at $250{ }^{\circ} \mathrm{C}$ was higher than that obtained at $150{ }^{\circ} \mathrm{C}$. This shows that temperature affects both the reaction time and gaseous yield. At a higher temperature of $250{ }^{\circ} \mathrm{C}$ the reaction was sped up thus lowering the reaction time [11]. This becomes evident that high temperature supports easy cleavage of bonds and thus speeds up the reaction and lowers the reaction time. HDPE with a long linear polymer chain with low branching and high degree of crystalinity led to high strength properties and thus required higher temperature and more reaction time.

From the result in Table 2 and Fig. 5, the reaction occurred at a catalyst of 1:16 and the concentration of gases obtained at $150{ }^{\circ} \mathrm{C}$ were slightly higher than the gases collected at $250{ }^{\circ} \mathrm{C}$. This is an indication that the total products decreased slightly with increase in temperature [12].

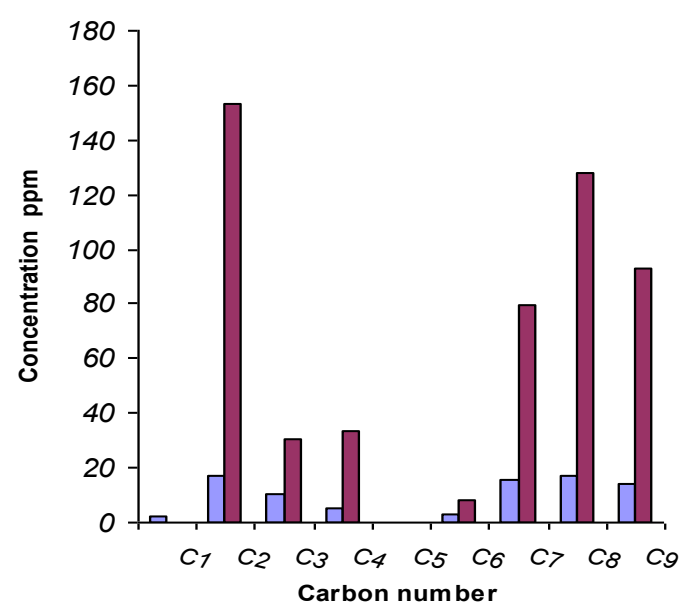

Fig. 4. Composition of gases obtained from pyrolysis of HDPE at $150{ }^{\circ} \mathrm{C}$ and $250{ }^{\circ} \mathrm{C}$ using fresh FCC catalyst with the catalyst/sample ratio of $1: 8$

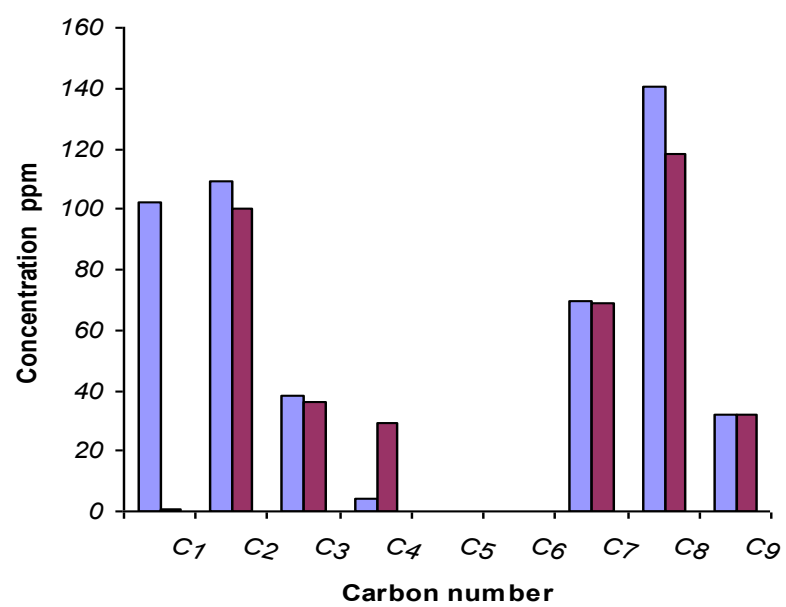

Fig. 5. Composition of gases obtained from pyrolysis of HDPE at $150{ }^{\circ} \mathrm{C}$ and $250{ }^{\circ} \mathrm{C}$ using fresh FCC catalyst with the catalyst/sample ratio of $1: 16$

With the FCC catalyst in pyrolysis reaction, the activity of the catalyst is expected to drop with increasing coke yield this could have been the reason in the drop of the total of the gaseous products in the reaction at $250{ }^{\circ} \mathrm{C}$.

The composition of gas was analyzed as given from the result in Tables 1 and 2 as well as Figures 2 and 3 respectively. These show that the dominant components could be observed in $\left\{\mathrm{C}_{2}\right.$ (17.3379 ppm), $C_{3}(10.7678 \mathrm{ppm}), \mathrm{C}_{6}(15.3558 \mathrm{ppm}), \mathrm{C}_{8}$ (16.8334 ppm) $\}$ and $\left\{\mathrm{C}_{2}(152.9045), \mathrm{C}_{3}(30.4014\right.$ ppm), $\mathrm{C}_{4}(33.5009 \mathrm{ppm}), \mathrm{C}_{7}(79.5571 \mathrm{ppm}), \mathrm{C}_{8}$ (127.8764 ppm) and $\left.\mathrm{C}_{9}(93.2789 \mathrm{ppm})\right\}$ respectively. In every case one of the dominant components could be observed in $\mathrm{C}_{2}$. This could be explained relating with the structure and degradation pattern of polyethylene because it is built up from $\mathrm{C}_{2}$ monomers [13]. 
Table 3: Composition of gases obtained from pyrolysis of HDPE at $150{ }^{\circ} \mathrm{C}$ and $250{ }^{\circ} \mathrm{C}$ with spent FCC catalyst using catalyst/sample ratio of 1:8 after heating for one and a half hours.

\begin{tabular}{|c|c|c|c|c|c|}
\hline \multirow{2}{*}{ Component } & \multirow{2}{*}{$\begin{array}{c}\text { Organic } \\
\text { Compound }\end{array}$} & \multicolumn{2}{|c|}{ Reaction at $150^{\circ} \mathrm{C}$} & \multicolumn{2}{|c|}{ Reaction at $250^{\circ} \mathrm{C}$} \\
\hline & & $\begin{array}{c}\text { Concentration } \\
\text { ppm }\end{array}$ & $\begin{array}{c}(\%) \\
\text { Concentration }\end{array}$ & $\begin{array}{c}\text { Concentration } \\
\text { ppm }\end{array}$ & $\begin{array}{c}(\%) \\
\text { Concentration }\end{array}$ \\
\hline $\mathrm{C}_{1}$ & n-Methane & 1.6735 & 1.4845 & 1.7855 & 2.0440 \\
\hline $\mathrm{C}_{2}$ & n-Ethane & 0.0051 & 0.0045 & 0.0109 & 0.0124 \\
\hline $\mathrm{C}_{3}$ & n-Propane & 0.9277 & 0.8229 & 3.3977 & 3.8890 \\
\hline $\mathrm{C}_{4}$ & n-Butane & 15.4172 & 13.6760 & Nil & Nil \\
\hline $\mathrm{C}_{5}$ & n-Pentane & 70.3596 & 62.4150 & 51.2582 & 58.6790 \\
\hline $\mathrm{C}_{6}$ & n-Hexane & 0.0041 & 0.0036 & 0.0035 & 0.0040 \\
\hline $\mathrm{C}_{7}$ & n-Heptane & Nil & Nil & 4.7962 & 5.4900 \\
\hline $\mathrm{C}_{8}$ & n-Octane & 3.6629 & 3.2493 & 6.2605 & 7.1668 \\
\hline $\mathrm{C}_{9}$ & n-Nonane & 20.6775 & 18.3420 & 19.8404 & 22.7120 \\
\hline $\mathrm{C}_{10}$ & n-Decane & Nil & Nil & Nil & Nil \\
\hline Total & & 112.7276 & & 87.3531 & \\
\hline
\end{tabular}

From the results in Table 3, the total concentration of gaseous products obtained at $150^{\circ} \mathrm{C}$ was 112.7276 ppm while that obtained at $250^{\circ} \mathrm{C}$ gave 87.3531 ppm. This means that the effect of the catalyst on the yield and distribution of the product became less

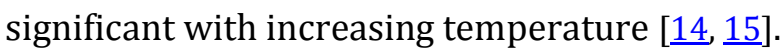

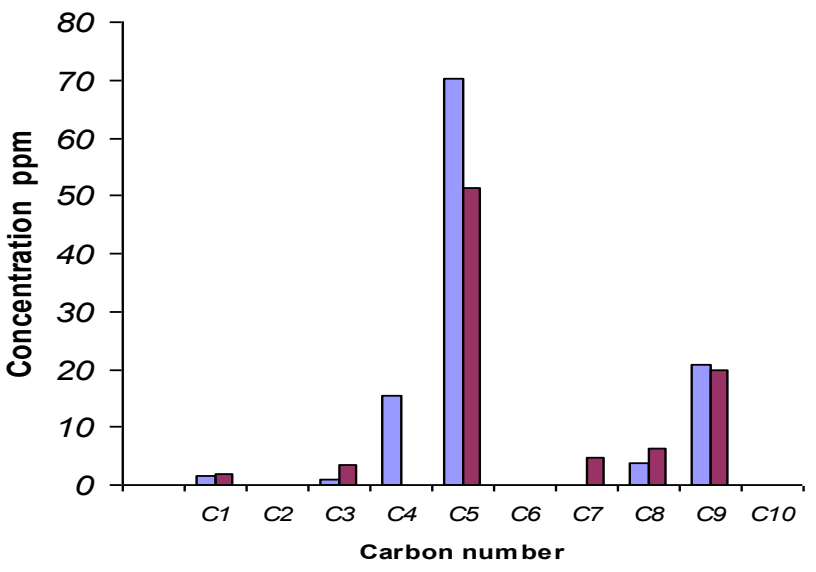

Figure 6: composition of gases obtained $150^{\circ} \mathrm{C}$ and $250{ }^{\circ} \mathrm{C}$ using spent FCC catalyst at ratio $1: 16$
The dominant components in the reaction as shown in Fig 6 were observed in $\left.C_{4} 15.4172 \mathrm{ppm}\right), \mathrm{C}_{5}$ (70.3596 ppm) and $\mathrm{C}_{9}(20.6775 \mathrm{ppm})$.

Again this result revealed that the dominant gases were within the gasoline range which is typical of FCC catalysts. The total concentration of gases obtained at $250{ }^{\circ} \mathrm{C}$ with fresh FCC catalyst using the same sample at the same catalyst/sample ratio yielded higher concentration of gases. This could be as a result of coke formation which diminishes the action of FCC catalyst [16]. The yield of gases obtained were however greater than those obtained through thermal pyrolysis.

In Table 4, the pyrolysis data from HDPE which occurred at 150 and $250{ }^{\circ} \mathrm{C}$ using catalyst/sample ratio of $1: 16$ are being presented. From the results the total concentration of gaseous products collected 
at 150 ? $250{ }^{\circ} \mathrm{C}$ were obtained to be (116.9178 ppm) and (109.4314 ppm) respectively. The dominant components were observed in $\mathrm{C}_{5}(78.0995 \mathrm{ppm})$ and $\mathrm{C}_{9}\left(18.2544 \mathrm{ppm}\right.$ for gases collected at $150{ }^{\circ} \mathrm{C}$. On the other hand $\mathrm{C}_{5}(42.0682 \mathrm{ppm}) \mathrm{C}_{7}(12.4087 \mathrm{ppm}), \mathrm{C}_{8}$ (8.8217 ppm) and $\mathrm{C}_{9}(37.4087 \mathrm{ppm})$ were the dominant components observed in the gases collected at $250{ }^{\circ} \mathrm{C}$. The gas yield was higher at 250 OC which became evident that the effect of the catalyst on the pyrolysis of HDPE on the yields and distribution of the products were significant with increasing temperature.

Generally, the spent FCC catalyst has high activity for hydrocarbon cracking reactions and selectivity to non-aromatic $\mathrm{C}_{5}$ ? $\mathrm{C}_{11}$ hydrocarbons which are evident in all the results from the samples see Table 4. Olefins which were also revealed as part of results obtained by using spent FCC catalyst [17].

Generally the spent catalysts are expected to show diminishing activity but then, there were still significantly effective in the pyrolysis reaction as the spent FCC catalyst was able to show high cracking activity, yielding better gasoline range products than in purely thermal cracking [18]. This result agrees with the result presented on the catalytic pyrolysis of polystyrene over ZSM ? 5 Mordenite, sulphur

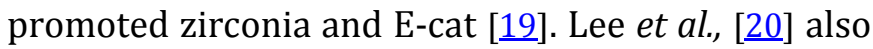
observed that at $430{ }^{\circ} \mathrm{C}$ in a semi batch reaction the pyrolysis of HDPE using E-cat showed high cracking activity and yielding better liquid gasoline products than in purely thermal cracking.
The values of the gas concentrations however showed that there was a decrease in the concentration of gases which could be attributed to the formation of coke entrapped in the pore of the catalyst thereby diminishing its activity with time [15].

Gas chromatographic analysis generally revealed that the components of gases were in the range of $\mathrm{C}_{1}$ $C_{9},[\underline{21}, \underline{22}]$. The gases are very useful for example $C_{1}$ ${ }_{0} \mathrm{C}_{4}$ gases can be used in diverse ways. Methane also known as marsh gas is the main component in natural gas; it is a colourless odourless and flammable gas. Ethane is also a colourless and odourless gas and the second most abundant component in natural gas. Ethane is also used to produce ethylene which is a raw material for the production of plastic material. Another use is as a refregerant. Propane is also a flammable hydrocarbon in the alkane series, which is also present in natural gas and used as bottled gas. It finds other uses in fuel engine, oxy-gas torches and portable stores [르, 24]. Butane undergoes free radical chlorination to form chlorobenzene and chlorobutane as well as other derivations. Butane is also used as a fed stock for production of ethylene. It is used in refineries to enhance octane member of motor gasoline when blended with propane and other hydrocarbon may be referred commercially LPG. It is also used as a fuel in lighter and propellants in aerosol sprays.

The other gases obtained were within the range of $\mathrm{C}_{5}-\mathrm{C}_{9}$. The gases are also very useful for example, pentane which is a colourless gas with the odour of 
petroleum similarly n-hexane is also a colourless gas with petroleum like odour. Hexane however, is also used to extract vegetable oil from crops such as Soyabean etc. It is also used in cleaning textile, and printing and cleaning furniture. Some glue used in roofing and shoe leather container hexane. Quick drying glues also contain n-hexane it is also contained in gasoline. $\mathrm{N}$-heptane and $\mathrm{n}$-octane has the odour of gasoline and are considered as a component of gasoline. Nonane a colourless flammable liquid occurs primarily in the component of petroleum distilled fraction commonly called kerosene which is used in fueling tractors or as jet fuel. It is also used as a fuel additive and as a fuel additive and as a component in biodegradable detergent.

Table 4: Pyrolysis data from HDPE which occurred at 150 and $250{ }^{\circ} \mathrm{C}$ using spent catalyst/sample ratio of 1:16

\begin{tabular}{cccccc}
\hline & & \multicolumn{2}{c}{ Reaction at 150 ${ }^{\circ} \mathbf{C}$} & \multicolumn{2}{c}{ Reaction at $\mathbf{2 5 0}{ }^{\circ} \mathbf{C}$} \\
Component & $\begin{array}{c}\text { Organic } \\
\text { compound }\end{array}$ & $\begin{array}{c}\text { Concentration } \\
\text { ppm }\end{array}$ & $\begin{array}{c}\text { (\%) } \\
\text { Concentration }\end{array}$ & $\begin{array}{c}\text { Concentration } \\
\text { ppm }\end{array}$ & $\begin{array}{c}\text { (\%) } \\
\text { Concentration }\end{array}$ \\
\hline$C_{1}$ & n-Methane & 1.0875 & 0.0093 & 0.9115 & 0.8329 \\
$\mathrm{C}_{2}$ & n-Ethane & 0.0066 & 0.0056 & 0.0185 & 0.0169 \\
$\mathrm{C}_{3}$ & n-Propane & 1.4538 & 1.2434 & 2.7350 & 2.4990 \\
$\mathrm{C}_{4}$ & n-Butane & 14.1784 & 12.1260 & 5.2807 & 4.8250 \\
$\mathrm{C}_{5}$ & n-Pentane & 78.0995 & 66.7980 & 42.0682 & 38.4420 \\
$\mathrm{C}_{6}$ & n-Hexane & 0.0041 & 0.0035 & 0.0068 & 0.0060 \\
$\mathrm{C}_{7}$ & n-Heptane & Nil & Nil & 12.4087 & 11.3390 \\
$\mathrm{C}_{8}$ & n-Octane & 3.6335 & 3.1077 & 8.8217 & 8.0613 \\
$\mathrm{C}_{9}$ & n-Nonane & 18.2544 & 15.6130 & 37.1803 & 33.9750 \\
$\mathrm{C}_{10}$ & n-Decane & Nil & Nil & Nil & Nil \\
Total & & $\mathbf{1 1 6 . 9 1 7 8}$ & & $\mathbf{1 0 9 . 4 3 1 4}$ & \\
\hline
\end{tabular}

\section{Conclusion}

In this work, thermo-catalytic pyrolysis of contaminated high density polyethylene (HDPE) was studied using fresh and spent FCC catalyst. It was observed that the pyrolysis reaction gave aliphatic hydrocarbon within the range of $\left(\mathrm{C}_{1}-\mathrm{C}_{4}\right.$; $\left.\mathrm{C}_{5}-\mathrm{C}_{9}\right)$ and $\left(\mathrm{C}_{1}-\mathrm{C}_{4} ; \mathrm{C}_{7}-\mathrm{C}_{9}\right)$ for the reactions which occurred using catalyst/sample ratios of $1: 8$ and 1:16 respectively. The corresponding carbon number obtained using spent FCC catalyst $\left(\mathrm{C}_{1}-\mathrm{C}_{4}\right.$;
$\mathrm{C}_{7}-\mathrm{C}_{9}$ ) using catalyst/sample ratio of $1: 8$ and 1:16 respectively. From these results, it became obvious that the FCC catalyst resulted in more gasoline range products as higher values were obtained within the range of $\mathrm{C}_{7}-\mathrm{C}_{9}$. The FCC catalyst used also gave high activity for hydrocarbon cracking reactions and selectivity of $\mathrm{C}_{7}-\mathrm{C}_{9}$. High values of $\mathrm{C}_{2}$ carbon atoms were also obtained from the reactions using both fresh and spent FCC catalysts. 
The pyrolysis of HDPE has not only reduced the solid waste by $50 \% ; 62.5 \%$ and $55 \% ; 60 \%$ by volume for the fresh and spent FCC catalyst for the reactions which occurred using catalyst/sample ratios of 1:8 and 1:16 respectively, useful gases which can be fractionated into fuel gases, gasoline range gases and organic solvents were also obtained. The result obtained showed that temperature affects both the reaction time and gaseous yield. High temperature supports easy cleavage of bonds

\section{References}

[1] F. Recycling. (2006), Scheirs, J., Kaminsky, W., Eds.

[2] D. Almeida and M.d.F. Marques, Thermal and catalytic pyrolysis of plastic waste. Polimeros, 26 (2016) 44-51.

[3] M.S. Abbas-Abadi, M.N. Haghighi and H. Yeganeh, Evaluation of pyrolysis product of virgin high density polyethylene degradation using different process parameters in a stirred reactor. Fuel processing technology, 109 (2013) 90-95.

[4] M.N. Siddiqui and H.H. Redhwi, Catalytic coprocessing of waste plastics and petroleum residue into liquid fuel oils. Journal of Analytical and Applied Pyrolysis, 86 (2009) 141-147.

[5] F. Pinto, P. Costa, I. Gulyurtlu and I. Cabrita, Pyrolysis of plastic wastes: 2. Effect of catalyst on product yield. Journal of Analytical and Applied Pyrolysis, 51 (1999) 57-71.

[6] E. Fujiwara, Code Design for Dependable Systems. (2006): Wiley Online Library.

[7] N. Surma, P. Tor and G. Ijuo, Low Temperature Catalytic Pyrolysis of Polyethylene Terephthalate. International Journal of Advanced Research in Chemical Science, 5 (2018)

[8] Chemical engineering kinetics. J. M. Smith. McGrawHill Book Cpmpany, Inc., New York (1956). 402 pages. \$8.00. AIChE Journal, 3 (1957) 12S$12 \mathrm{~S}$.

[9] C. Osueke and I. Ofondu, Conversion of waste plastics (polyethylene) to fuel by means of pyrolysis. Int J Adv Eng Sci Technol, 4 (2011) 21-24.

[10] S. Abdulkareem, N. Eleburuike and T. Amoloye, Comparison of Fuel oil from Thermal Cracking and Catalytic cracking of high density resulting in increased reaction rate thereby lowering the reaction time. Also, the effect of the catalyst on the yield and distribution of the product became less significant with increasing temperature. Fresh FCC catalyst unsurprisingly gave higher gaseous yield than the spent.

Declaration of interest: There are no conflict of interest, as such, this summary statement will be ultimately published if the article is accepted.

polyethylene. J. Chem. Soc. Nigeria, 39 (2014) 103-106.

[11] S. Kumar and R. Singh, Recovery of hydrocarbon liquid from waste high density polyethylene by thermal pyrolysis. Brazilian journal of chemical engineering, 28 (2011) 659-667.

[12] M. del Remedio Hernández, Á.N. García and A. Marcilla, Study of the gases obtained in thermal and catalytic flash pyrolysis of HDPE in a fluidized bed reactor. Journal of analytical and applied pyrolysis, 73 (2005) 314-322.

[13] R. Jalilian and A. Taheri, Synthesis and application of a novel core-shell-shell magnetic ion imprinted polymer as a selective adsorbent of trace amounts of silver ions. e-Polymers, 18 (2018) 123-134.

[14] N. Miskolczi, L. Bartha, G. Deak and B. Jover, Thermal degradation of municipal plastic waste for production of fuel-like hydrocarbons. Polymer Degradation and Stability, 86 (2004) 357-366.

[15] G. Manos, A. Garforth and J. Dwyer, Catalytic degradation of high-density polyethylene over different zeolitic structures. Industrial \& engineering chemistry research, 39 (2000) 1198-1202.

[16] I. Ofoma. (2006), Georgia Institute of Technology.

[17] I. Barbarias, M. Artetxe, A. Arregi, J. Alvarez, G. Lopez, M. Amutio and M. Olazar, Catalytic cracking of HDPE pyrolysis volatiles over a spent FCC catalyst. CHEMICAL ENGINEERING, 43 (2015) 1-6.

[18] N. Surma, G. Ijuo and P.N. Tor, Useful Products from Waste Polythylene Terepthalate via Low 
Temperature Cayalytic Pyrolysis. Chemical Research Journal, 3 (2018) 57-63.

[19] G. De la Puente and U. Sedran, Recycling polystyrene into fuels by means of FCC: performance of various acidic catalysts. Applied Catalysis B: Environmental, 19 (1998) 305311.

[20] K.-H. Lee and D.-H. Shin, Catalytic degradation of waste polyolefinic polymers using spent FCC catalyst with various experimental variables. Korean Journal of Chemical Engineering, 20 (2003) 89-92.

[21] H. Zeng, F. Zou, E. Lehne, J.Y. Zuo and D. Zhang, Gas chromatograph applications in petroleum hydrocarbon fluids. Advanced gas chromatography $\square$ progress in agricultural, biomedical and industrial applications, InTech, (2012) 363-388.

[22] Y. Wang, Q. Chen, D.L. Norwood and J. McCaffrey, Recent development in the applications of comprehensive two-dimensional gas chromatograph. Journal of Liquid Chromatography \& Related Technologies, 33 (2010) 1082-1115.

[23] D.D. Link, C.E. Taylor and E.P. Ladner, Novel techniques for the conversion of methane hydrates, in Studies in Surface Science and Catalysis. (2001), Elsevier. 543-548.

[24] B. Coto, J. Coutinho, C. Martos, M. Robustillo, J. Espada and J.L. Pena, Assessment and improvement of $\mathrm{n}$-paraffin distribution obtained by HTGC to predict accurately crude oil cold properties. Energy \& Fuels, 25 (2011) 11531160. 